\title{
Growth hormone endocrinology of Atlantic salmon (Salmo salar): pituitary gene expression, hormone storage, secretion and plasma levels during parr-smolt transformation
}

\author{
T Ágústsson, K Sundell, T Sakamoto ${ }^{1}$, V Johansson, M Ando ${ }^{1}$ \\ and B Th Björnsson \\ Fish Endocrinology Laboratory, Department of Zoology, Göteborg University, Box 463, S 405 30, Göteborg, Sweden \\ ${ }^{1}$ Hiroshima University, Faculty of Integrated Arts and Sciences, 1-7-1 Kagamiyama, Higashihiroshima 739, Japan \\ (Requests for offprints should be addressed to B Th Björnsson; Email: thrandur.bjornsson@zool.gu.se)
}

\begin{abstract}
A number of studies on the Atlantic salmon (Salmo salar), have reported changes in plasma GH during parr-smolt transformation, but there is a lack of information about the endocrinology of the GH system during this process. In order to elucidate the mechanisms underlying these changes in plasma GH levels during the parr-smolt transformation of Atlantic salmon, GH mRNA expression in the pituitary was studied together with total pituitary $\mathrm{GH}$ content, in vitro $\mathrm{GH}$ secretion rate and plasma GH and IGF-I levels. Atlantic salmon were kept in outside tanks, under natural condition from early February until late June. Approximately three times a month fish were killed and pituitaries and blood were sampled for investigation. Further, pituitaries were moved to the laboratory for in vitro $\mathrm{GH}$ secretion studies. The results show that the GH system is first activated by an increase in GH secretion
\end{abstract}

rate, which leads to an increase in plasma GH levels and causes a drop in the total GH content of the pituitary. This drop in pituitary GH content is later reversed by an increased GH synthesis seen as an increase in GH mRNA expression. Maximal activation of the GH system is seen to occur in early May, when plasma IGF-I levels reach highest levels, after which a certain deactivation of the GH system takes place. The data show that plasma levels of $\mathrm{GH}$ are to a large extent regulated by the secretion rate from the pituitary, although changes in the $\mathrm{GH}$ clearance rate are also likely to take place and influence the plasma $\mathrm{GH}$ levels. The study further underlines the significant role that the GH-IGF-I axis plays in the parr-smolt transformation of the Atlantic salmon.

Journal of Endocrinology (2001) 170, 227-234

\section{Introduction}

For growth hormone $(\mathrm{GH})$, as for other endocrine factors, plasma levels are the result of secretion and clearance rates. Changes in circulating levels can be due to changes in either parameter. Thus, although increased plasma GH levels in salmonid fish are generally interpreted as the result of increased pituitary secretion, the extremely high $\mathrm{GH}$ levels during growth retardation have instead been explained by a down-regulation of hepatic GH receptors and lower clearance rate (Gray et al. 1990). Likewise, a change, e.g. a decrease, in pituitary GH content can be interpreted either as being the result of decreased synthesis rate or due to increased secretion rate. Thus, a measurement of a single GH-related parameter may not reveal if the GH system is activated or not. Data that help elucidate the causal relationships of $\mathrm{GH}$ dynamics, from gene expression, pituitary storage and secretion, and circulating levels, to peripheral physiological actions, are scarce. In salmonids, plasma GH levels usually increase transiently following seawater (SW) entry (see Björnsson 1997). In coho salmon (Oncorhynchus kisutch) and rainbow trout (O. mykiss), both the clearance rate and the calculated secretion rate of $\mathrm{GH}$ increased after transfer to SW (Sakamoto et al. 1990, 1991). Also, in amago salmon (O. masou), the response of GH mRNA to SW exposure appears to be related to the development of preparatory mechanisms for SW entry, indicating that GH mRNA increases before SW entry (Yada et al. 1992).

The parr-smolt transformation (smoltification) of anadromous salmonids is a very good model for studying the dynamics of the GH endocrine system. It is a welldefined life-history stage that involves profound physiological and biochemical changes with enhanced SW adaptability as one of the characteristic features (McCormick \& Saunders 1987, Hoar 1988). Plasma GH levels increase significantly during smoltification and the hormone is considered to be one of the main regulators of 
this developmental process, improving hypoosmoregulatory ability, as well as regulating growth and behaviour (Björnsson 1997). The smoltification process represents therefore a period where the GH system is highly activated.

The actions of GH may in part be mediated by insulinlike growth factor I (IGF-I) according to the dual effector hypothesis of action (Isaksson et al. 1987, Daughaday \& Rotwein 1989), and/or have a role in a feed-back control of $\mathrm{GH}$ secretion as has recently been demonstrated in mice (Sjögren et al. 1999). Although IGF-I is expressed locally in many tissues, in mice it has recently been shown that the circulating IGF-I levels are primarily of hepatic origin (Sjögren et al. 1999, Yakar et al. 1999).

Data on fish reveal that the GH-IGF-I axis controlling growth has been highly conserved during vertebrate evolution (Bern et al. 1991, Siharath \& Bern 1993, Duan 1997). In salmonids, the highest tissue density of GH receptors is in the liver (Sakamoto \& Hirano 1991), and plasma IGF-I levels increase following GH treatment (Moriyama 1995). During salmon smoltification, liver IGF-I mRNA levels increase (Duan et al. 1995) and IGF-I along with GH can improve salinity tolerance (McCormick 1996), further indicating the synergy of these two hormones. For salmonids, as for other vertebrates, the circulating levels of IGF-I are thus likely to be a good indicator of peripheral $\mathrm{GH}$ action.

In order to elucidate some of the mechanisms underlying changes in circulating $\mathrm{GH}$ levels, the parr-smolt transformation of the Atlantic salmon was used as a model. A concomitant assessment of pituitary GH gene expression, and GH storage and secretion, was made to establish the chain of events leading to the observed changes in plasma GH. Further, plasma IGF-I levels were assessed as a measure of the peripheral action of $\mathrm{GH}$, and to increase the understanding of the interplay between these two factors during this crucial developmental stage of the Atlantic salmon.

\section{Materials and Methods}

\section{Fish and holding conditions}

Juvenile Atlantic salmon, Salmo salar, (mean size $43 \pm 0.7 \mathrm{~g}$ (S.E.M.) body weight (BW) and $16 \pm 0 \cdot 1 \mathrm{~cm}$ fork length) were obtained from and kept at a local hatchery, Fiskeman i Laxforsen AB, Anneberg, Sweden. At the start of the experimental period, on 4 January 1998, 250 salmon were transferred to each of two replicate $1 \mathrm{~m}^{3}$ outdoor tanks under a natural photoperiod. The tanks were supplied by water from a nearby stream at ambient temperature, rising gradually from 2 to $10^{\circ} \mathrm{C}$ during the experimental period. The fish were fed commercial dry pellets, according to a feeding schedule used by the hatchery (EWOS (Livingston, UK), aquaculture feeding tables).

\section{Experimental design}

Sampling was conducted on 12 occasions from 4 February to 30 June; every second week during February and March, and then every tenth day. On each sampling date, from 1000 to 1600 h, 30 fish were sampled, 15 from each tank (some of the fish were sampled for purposes other than reported in this study). On each occasion, the fish were randomly netted (three times there were four fish and once three fish from each tank) and immediately killed by an overdose of anaesthetic (0.05\% 2-phenoxyethanol/1; Sigma Chemical Co., St Louis, MO, USA). Then, the fish were weighed (wet weight) and measured (fork length), after which blood was drawn from the caudal vessels using $1 \mathrm{ml}$ heparinised syringes. The blood was centrifuged at $3000 \mathrm{~g}$ for $5 \mathrm{~min}$ to obtain plasma, which was aliquoted, frozen immediately on dry ice and then stored at $-80{ }^{\circ} \mathrm{C}$ until analyses. The pituitaries were then dissected out. Five and eight pituitaries were frozen in liquid nitrogen and stored at $-80{ }^{\circ} \mathrm{C}$ for later analyses of $\mathrm{GH}$ mRNA and total GH content respectively. Another eight pituitaries were placed in ice-cold Hanks' balanced salt solution (HBSS) and transferred to the laboratory for measurement of $\mathrm{GH}$ secretion rate.

\section{Plasma levels of GH and IGF-I}

Plasma GH levels were measured by an RIA specific for salmon GH (Björnsson et al. 1994) and IGF-I levels were assessed using an RIA protocol by Moriyama et al. (1994).

\section{In vitro perifusions}

On each sampling date pituitaries were obtained from eight fish. Each pituitary was transferred to a perifusion chamber, made from a part of a $1 \mathrm{ml}$ syringe barrel, containing $0.5 \mathrm{ml}$ modified HBSS (containing $15 \mathrm{mM}$ Hepes and $0 \cdot 1 \%$ BSA (Sigma)) and placed between two layers of (approximately $0.05 \mathrm{~g}$ ) microcarrier beads (Cytodex 1; Sigma) pre-swollen in HBSS. A temperaturecontrolled cooling mantle was placed around each perifusion chamber to keep the pituitaries at $10{ }^{\circ} \mathrm{C}$ (Fig. 1).

The pituitaries were perifused with HBSS at a constant rate of $15 \mathrm{ml} / \mathrm{h}$ using a peristaltic pump. The reservoir containing HBSS solution was placed at the same height as the perifusion chambers to avoid pressure changes. In order to establish a reliable measure of secretion rate, the pituitaries were perifused for $3 \mathrm{~h}$. The perifusate from the first hour, during which a base-line secretion rate was established (Ágústsson et al. 2000, Ágústsson \& Björnsson 2000), was discarded. Five-minute fractions were collected during the last $2 \mathrm{~h}$ of the perifusion, frozen and stored at $-80{ }^{\circ} \mathrm{C}$ until analysis. For each pituitary, the secretion rate was calculated as the mean of all fractions (ng GH/ pituitary per min), and then, a group mean was calculated for the eight individuals. No secretion rate measurements 


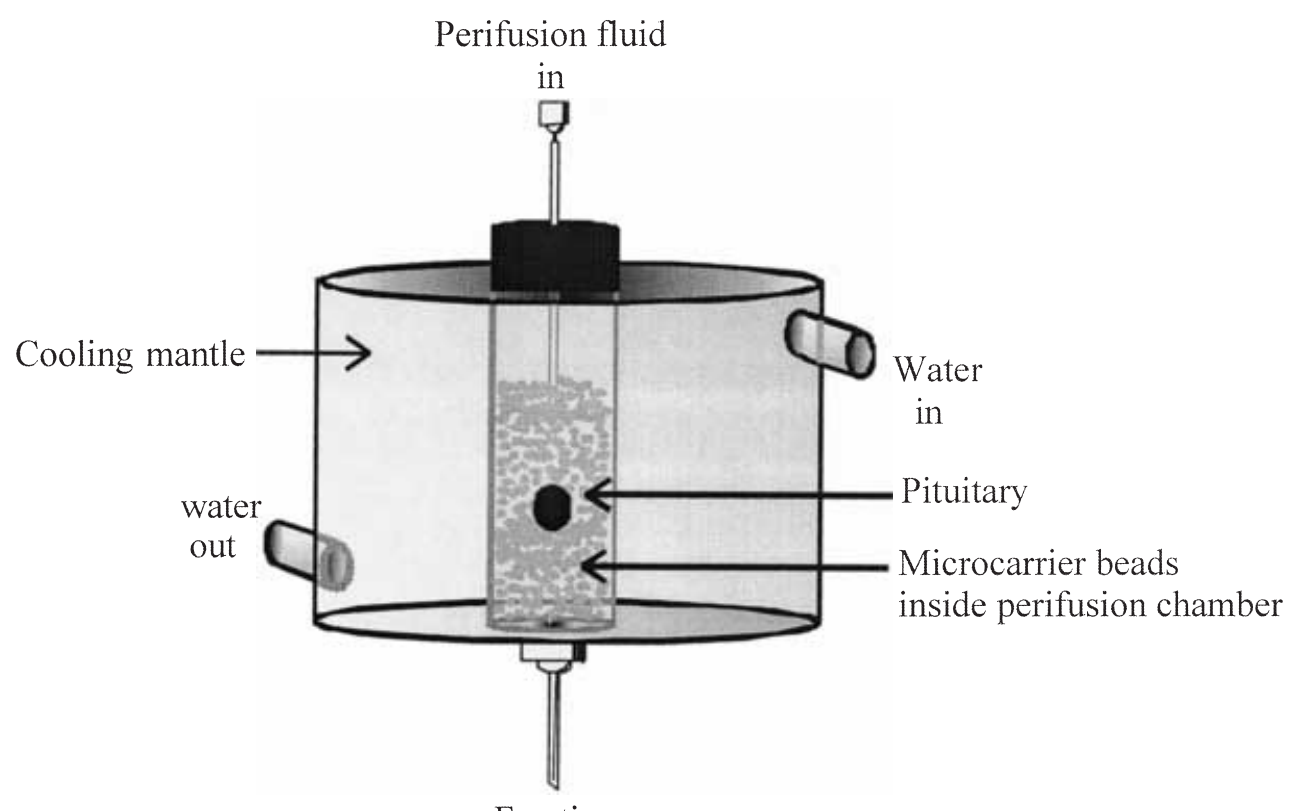

Fractions

Figure 1 In vitro perifusion chamber for measurement of whole pituitary $\mathrm{GH}$ secretion. The chamber is made from a part of a $1 \mathrm{ml}$ syringe barrel containing $0.5 \mathrm{ml}$ modified HBSS, with $15 \mathrm{mM}$ Hepes and $0 \cdot 1 \%$ BSA. The pituitary is placed between two layers of (approximately $0.05 \mathrm{~g}$ ) microcarrier beads pre-swollen in HBSS. Each syringe barrel is then placed inside a cooling mantle with recirculating water to keep an optimum temperature of $10{ }^{\circ} \mathrm{C}$.

could be carried out in late March and early May due to technical problems.

\section{Pituitary GH content}

Pituitaries from 8-20 fish from each sampling date were sonicated separately in $200 \mu \mathrm{l}$ RIA buffer. After centrifugation, the supernatant was serially diluted to reach a valid $\mathrm{GH}$ detection range. $\mathrm{GH}$ levels in plasma $(\mathrm{ng} / \mathrm{ml})$, pituitary homogenate (recalculated as ng/pituitary per $\mathrm{g}$ BW) and pituitary perifusion fluid (ng/pituitary per min) were analysed by a specific salmon GH RIA (Björnsson et al. 1994).

\section{GH gene expression}

Pituitaries from four to six fish from each sampling date were used for quantification of GH mRNA. Total RNA was extracted from individual pituitaries using an RNA purification kit (Isogen; Wako Chemical, Osaka, Japan). All pituitaries were extracted at the same time to avoid procedure variability among the groups. Extracted RNA samples were dissolved in $10 \mu \mathrm{l}$ ultra pure water and stored at $-80{ }^{\circ} \mathrm{C}$ until Northern blot analysis. Oligonucleotide probes (40 mers) for salmon GH corresponding to nucleotides 60-99 of the GH I cDNA of rainbow trout, were labelled at the $3^{\prime}$-end with $\left[{ }^{32} \mathrm{P}\right] \mathrm{dATP}$, using a labelling kit
(N4020; Amersham, Arlington Heights, IL, USA). Probe specificity was validated by Northern blot analysis and by competition tests used in in situ hybridisation studies (Yada et al. 1991, 1992). For Northern blot analysis, $1 \mu \mathrm{l}$ for each of the total RNA samples (containing 5.6 $\mu \mathrm{l}$ RNA reconstituted in $0.5 \%$ SDS) was electrophoresed through a $1.4 \%$ agarose-formaldehyde gel and transferred on to a nylon membrane (Hybond-N+; Amersham) by capillary blotting (Sambrook et al. 1989). The RNA was covalently attached to the membrane by baking at $80{ }^{\circ} \mathrm{C}$ for $2 \mathrm{~h}$ and by UV cross-linking. Following prehybridisation, the membranes were hybridised with the probe at $55^{\circ} \mathrm{C}$ for $18 \mathrm{~h}$ according to the method of Sambrook et al. (1989). The membranes were washed in $2 \times$ SSC and $0 \cdot 1 \%$ SDS at room temperature for $2 \times 10 \mathrm{~min}$. They were washed again with $1 \times \mathrm{SSC}$ containing $0.1 \% \operatorname{SDS}$ at $65^{\circ} \mathrm{C}$ for $2 \times 20 \mathrm{~min}, 0 \cdot 1 \times \mathrm{SSC}$ containing $0 \cdot 1 \% \mathrm{SDS}$ for $20 \mathrm{~min}$ at $65{ }^{\circ} \mathrm{C}$, and then rinsed at room temperature. Internal standard (a pooled pituitary GH mRNA sample) was used in all gels to normalise the relative amount of the $\mathrm{GH}$ mRNA among blots. Serial dilutions of the RNA demonstrated linearity between the amount of RNA and the hybridisation signals obtained (data not shown). The membranes were exposed to imaging plate (Fuji imaging plate-Bas III; Fuji Film, Tokyo, Japan). Intensity of the hybridisation signals was assessed with an Auto Image Analyser (Bas 2000; Fuji Film) and GH mRNA was 
represented in arbitrary units per pituitary. Molecular sizes were estimated relative to migration of RNA size marker (Toyobo, Osaka, Japan).

\section{Calculations and statistics}

Condition factor (CF) was calculated from BW (g) and fork length $(\mathrm{cm})$ according to the equation $(\mathrm{BW} /$ fork length $\left.{ }^{3}\right) \times 100$.

The duplicates were compared using one-way ANOVA. As no significant differences existed, these were grouped together for further analysis. All data were logtransformed in order to obtain homoscedasity, and then analysed using one-way ANOVA followed by a StudentNewman-Keuls (SNK) post-hoc test. Data are presented as means \pm S.E.M.

\section{Results}

\section{Growth and morphological changes}

During the study, the fish increased from $14 \cdot 8 \pm 0 \cdot 2$ to $18 \cdot 3 \pm 0.2 \mathrm{~cm}$ in length and from $36 \cdot 7 \pm 1 \cdot 3$ to $62 \cdot 7 \pm 2 \cdot 5 \mathrm{~g}$ in weight, with most of the growth occurring in May and June (Table 1). No change in CF was observed until a significant decrease occurred in early May $(P<0 \cdot 05)$. This decrease was reversed in late May followed by another decrease towards the end of the experiment (Table 1).

The fish exhibited a gradual loss of parr marks and increasing silvering during the experiment (data not shown).

\section{Pituitary GH mRNA expression}

In the pituitaries, $1.7 \mathrm{~kb}$ transcripts for $\mathrm{GH}$ were detected. From being close to average in early February until mid-March, the GH mRNA expression decreased gradually during April to as low as $15 \%$ of average $(P<0 \cdot 05$; Fig. 2a). From late April until mid-May, the mRNA expression increased from 15 to $132 \%(P<0 \cdot 05$; Fig. 2a), after which it decreased towards the average expression rate in June and July.

\section{Pituitary GH content}

No significant changes were observed in the total pituitary GH content during the first part of the study. From late March to early April, there was a significant increase in the pituitary $\mathrm{GH}$ content, from $0.35 \pm 0.07$ up to $6.31 \pm 0.59 \mu \mathrm{g} / \mathrm{ml}(P<0 \cdot 05$; Fig. $2 b)$. In early May, there was a significant decrease compared with the preceding measurement $(P<0 \cdot 05)$, before the pituitary GH content increased again (Fig. 2b).

\section{GH secretion in vitro}

The pituitary GH secretion was low during the first part of the study until mid-April. From late April (2.47 $\pm 0 \cdot 59 / \mathrm{ng}$

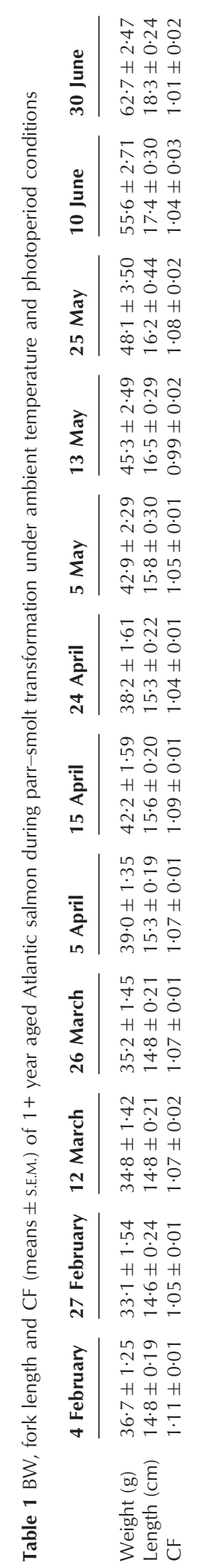

www.endocrinology.org 

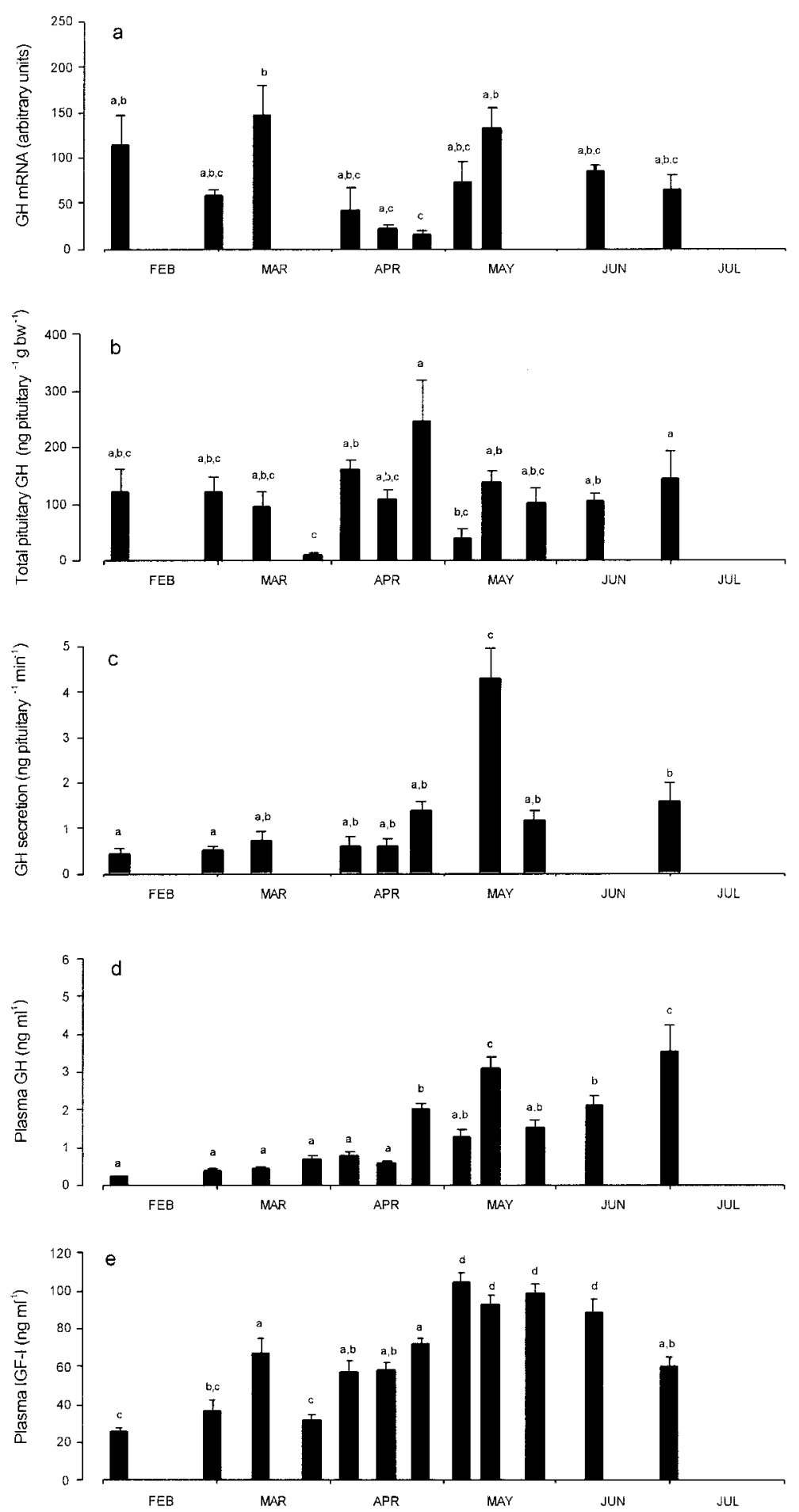

Figure 2 The GH-IGF-I endocrinology of 1+ year aged Atlantic salmon during parr-smolt transformation under ambient temperature and photoperiod conditions. (a) Pituitary GH mRNA levels $(n=4-6)$. (b) Pituitary GH content $(n=8-20)$. (c) In vitro GH secretion $(n=8)$. (d) GH plasma levels $(n=30)$. (e) IGF-I plasma levels $(n=30)$. Data bars are means with vertical lines indicating S.E.M. Data were analysed using one-way ANOVA followed by a post-hoc SNK test. Within each histogram, bars not sharing a superscript letter differ significantly $(P<0 \cdot 05)$. 
$\mathrm{ml})$ the $\mathrm{GH}$ secretion starts to increase, reaching significantly elevated levels in mid-May $(17 \cdot 2 \pm 2.54 \mathrm{ng} / \mathrm{ml})$. After this, a significant decrease occurred in late May $(P<0 \cdot 05$; Fig. 2c).

\section{Plasma GH levels}

No changes were observed in plasma levels during winter and early spring. Then, two peaks in plasma GH levels were observed (Fig. 2d), the first in late April $(P<0 \cdot 05)$, and a second in mid-May, being significantly higher than the previous one $(P<0 \cdot 05$; Fig. $2 \mathrm{~d})$. After these peaks, the plasma GH levels decreased before increasing again in June (Fig. 2d).

\section{Plasma IGF-I levels}

Two distinct peaks in plasma IGF-I levels were observed during the experiment. The first significant increase $(P<0 \cdot 05$; Fig. 2e) was observed in mid-March with a drop in late March. In early April, an increase in IGF-I levels was observed, becoming significant $(P<0 \cdot 05$; Fig. 2e) in early May. During May and until early June no significant changes were observed and the levels stayed high. In late June, the levels started to decrease and reached levels as seen in early April (Fig. 2e).

\section{Discussion}

During the parr-smolt transformation of the Atlantic salmon, a frequently observed feature is that the plasma GH profile has two or more distinct peaks (Prunet et al. 1989, Young et al. 1989a,b, Stefansson et al. 1991, McCormick et al. 1995, Björnsson et al. 2000). It has been speculated that this is due to interplay between GH secretion rate and the metabolic clearance rate of the hormone (Björnsson et al. 2000), but data explaining this have been lacking.

As the $\mathrm{GH}$ secretion rate is measured in vitro, the complex hypothalamic and peripheral feed-back control on GH secretion in vivo is removed. Thus, the obtained data may not fully represent the in vivo secretion rate, but rather the basal 'uncontrolled' secretion rate. Accepting that this is still an important component of the in vivo secretory activity, the present study indicates that the initial activation of the $\mathrm{GH}$ system during mid- to late April, when plasma GH levels start to increase, is caused by an increase in the GH secretion rate. This $\mathrm{GH}$ appears to come from pituitary stores, rather than new $\mathrm{GH}$ synthesis, as $\mathrm{GH}$ mRNA levels do not increase during this period. A likely reason why the GH content does not decline significantly is that the amount secreted is minor in relation to the total amount of GH stored.

From late April to mid-May, a second phase in the activation of the GH system is initiated, as the GH secretion rate continues to rise rapidly, in parallel with an increased GH gene expression. During this period, there is first a decline and then a rise in pituitary GH content, indicating that initially the secretion rate is in excess of the $\mathrm{GH}$ synthesis rate, but from early May, there is enough de novo $\mathrm{GH}$ synthesis to replace the $\mathrm{GH}$ secreted as well as increase pituitary GH content. Although a measurement of secretion rate is not available for early May, the increased gene expression and decreased pituitary content suggest that secretion is increased from late April to mid-May. It is therefore somewhat surprising that plasma GH levels decline temporarily in early May, before increasing again. The result is a typical 'split-peak' plasma $\mathrm{GH}$ profile as often seen during salmon smoltification (Prunet et al. 1989, Young et al. 1989a,b, Stefansson et al. 1991, McCormick et al. 1995, Björnsson et al. 2000). It has been speculated that this is due to an increased metabolic clearance rate of $\mathrm{GH}$ as a result of increased $\mathrm{GH}$ receptor expression in peripheral tissues, representing a third stage in the activation of the GH system. Although no data exist on $\mathrm{GH}$ receptor densities or $\mathrm{GH}$ clearance rate during smoltification, the process is a pre-adaptation to life in SW, and SW transfer of rainbow trout has been shown to increase GH clearance rate (Sakamoto et al. 1990).

From mid- to late May, a deactivation of the GH system appears to start as GH secretion decreases significantly, with a concomitant decline in plasma GH levels. At the same time, there is a slight trend towards lower GH gene expression while the GH pituitary content does not change markedly.

Towards the end of the study, from late May to early July, there is a gradual increase in plasma GH levels without any significant changes in pituitary GH parameters. This may indicate a further deactivation of the $\mathrm{GH}$ system and thus decreased clearance rate of $\mathrm{GH}$, due to a gradual down-regulation of GH receptors, as indicated by declining plasma IGF-I levels.

The above interpretation of the GH dynamics during the parr-smolt transformation and the peak in IGF-I plasma levels, suggest that the most intense GH stimulation of peripheral tissues occurs in early May. Physiological data from the fish of the presented study show that branchial $\mathrm{Na}^{+}, \mathrm{K}^{+}$-ATPase activity and intestinal fluid absorption are maximally stimulated in May (K Sundell, $\mathrm{T}$ Ágústsson \& B Th Björnsson, unpublished observations), further supporting the above interpretations, and the accepted role of $\mathrm{GH}$ as stimulator of hypoosmoregulatory ability (see Björnsson 1997). In interpreting the physiological significance of changes in total plasma IGF-I levels, it should be kept in mind that it is largely ( $>99 \%$ ) bound to specific IGF-I-binding proteins with the free IGF-I assumed to be the biologically active form (Shimizu et al. 1999).

It has been postulated from previous studies that there exists a 'light-pituitary' regulatory axis in salmonids (Komourdjian et al. 1976, Björnsson et al. 1989, 1995). These studies imply that increased photoperiod triggers an 
elevation in plasma levels of GH and thereby the onset of the parr-smolt transformation. As a result, this would then result in an increase in pituitary GH secretion as well as increased plasma GH levels, production and storage, which is in agreement with the presented findings.

In summary, this study demonstrates that the activation of the GH system during smoltification is a complex process, involving increases in GH secretion rate as well as increased GH synthesis, resulting in increased plasma GH levels. At the same time, the data indicate that $\mathrm{GH}$ clearance rate may increase due to increased $\mathrm{GH}$ receptor binding. This GH-activation sequence culminates in May with strong activation of the GH-IGF-I axis, which is in agreement with a SW-adapting role of $\mathrm{GH}$ during the smoltification of the Atlantic salmon.

\section{Acknowledgements}

The authors thank Elisabeth Jönsson and Gunilla Eriksson for their assistance during sampling. This study was financed by grants from the Swedish Council for Agricultural and Forestry Research and the Wallenberg Foundation VIRTUE project to B Th B and K S, by the Royal Society of Arts and Sciences in Göteborg and C F Lundströms Stiftelse to K S, by grants from the JapanScandinavia Sasakawa Foundation, Helge Ax:son Johnson Stiftelse, Wilhelm och Martina Lundgrens vetenskapsfond, Kungl och Hvitfeldtska Överskottsfonden and Hierta Retzius Stipendiefond to T Á, and by grants from the Ministry of Education and Fisheries Agency, Japan to T S.

\section{References}

Ágústsson T \& Björnsson BTh 2000 Growth hormone inhibits growth hormone secretion from the rainbow trout pituitary in vitro. Comparative Biochemistry and Physiology C: Comparative Pharmacology 126 299-303.

Ágústsson T, Ebbesson LOE \& Björnsson BTh 2000 Dopaminergic innervation of the rainbow trout pituitary and stimulatory effect of dopamine on growth hormone secretion in vitro. Comparative Biochemistry and Physiology A: Comparative Physiology 127 355-364.

Bern HA, McCormick SD, Kelley KM, Grau ES, Nishioka RS, Madsen SS \& Tsai PI 1991 Insulin-like growth factors 'under water': role in growth and function of fish and other poikilothermic vertebrates. In Modern Concepts of Insulin-Like Growth Factors, pp 85-96. Ed. EM Spencer. New York: Elsevier.

Björnsson BTh 1997 The biology of salmon growth hormone: from daylight to dominance. Fish Physiology and Biochemistry 17 9-24.

Björnsson BTh, Thorarensen H, Hirano T, Ogasawara T \& Kristinsson JB 1989 Photoperiod and temperature affect plasma growth hormone levels, growth, condition factor and hypoosmoregulatory ability of juvenile Atlantic salmon (Salmo salar) during parr-smolt transformation. Aquaculture 82 77-91.

Björnsson BTh, Taranger GL, Hansen T, Stefansson SO \& Haux C 1994 The interrelation between photoperiod, growth hormone and sexual maturation of adult Atlantic salmon (Salmo salar). General and Comparative Endocrinology $\mathbf{9 3}$ 70-81

Björnsson BTh, Stefansson SO \& Hansen T 1995 Photoperiod regulation of plasma growth hormone levels during parr-smolt transformation of Atlantic salmon: implications for hypoosmoregulatory ability and growth. General and Comparative Endocrinology 100 73-82.

Björnsson BTh, Hemre GI, Björnevik M \& Hansen T 2000 Photoperiod regulation of plasma growth hormone levels during induced smoltification of underyearling Atlantic salmon. General and Comparative Endocrinology 119 17-25.

Daughaday WH \& Rotwein P 1989 Insulin-like growth factors I and II. Peptide, messenger ribonucleic acid and gene structures, serum, and tissue concentrations. Endocrine Reviews 10 68-91.

Duan C 1997 The insulin-growth factor system and its biological actions in fish. American Zoologist 37 491-503.

Duan C, Plisetskaya EM \& Dickhoff WW 1995 Expression of insulin-like growth factor I in normally and abnormally developing salmon (Oncorhynchus kisutch). Endocrinology 136 446-452.

Gray ES, Young G \& Bern HA 1990 Radioreceptor assay for growth hormone in coho salmon (Oncorhynchus kisutch) and its application to the study of stunting. Journal of Experimental Zoology 256 290-296.

Hoar WS 1988 The physiology of smolting salmonids. In Fish Physiology, vol 11B, pp 275-343. Eds WS Hoar \& D Randall. Orlando, FL: Academic Press.

Isaksson OG, Lindahl A, Nilsson A \& Isgaard J 1987 Mechanism of the stimulatory effect of growth hormone on longitudinal bone growth. Endocrine Reviews 8 426-438.

Komourdjian MP, Saunders RL \& Fenwick JC 1976 The effects of porcine somatotropin on growth, and survival in seawater of Atlantic salmon (Salmo salar) parr. Canadian Journal of Zoology 54 531-535.

McCormick SD 1996 Effects of growth hormone and insulin-like growth factor I on salinity tolerance and gill $\mathrm{Na}^{+}, \mathrm{K}^{+}$-ATPase in Atlantic salmon (Salmo salar): interaction with cortisol. General and Comparative Endocrinology 101 3-11.

McCormick SD \& Saunders RL 1987 Preparatory physiological adaptations for marine life in salmonids: osmoregulation, growth and metabolism. American Fishing Society Symposium 1 211-229.

McCormick SD, Björnsson BTh, Sheridan M, Eilertson C, Carey JB \& O'Dea M 1995 Increased daylength stimulates plasma growth hormone and gill $\mathrm{Na}^{+}, \mathrm{K}^{+}$-ATPase in Atlantic salmon (Salmo salar). Journal of Comparative Physiology B: Comparative Biochemistry 165 $245-254$

Moriyama S 1995 Increased plasma insulin-like growth factor-I (IGF-I) following oral and intraperitoneal administration of growth hormone to rainbow trout, Oncorhynchus mykiss. Growth Regulation $\mathbf{5}$ 164-167.

Moriyama S, Swanson P, Nishii M, Takahashi A, Kawauchi H, Dickhoff WW \& Plisetskaya EM 1994 Development of homologous radioimmunoassay for coho salmon insulin-like growth factor-I. General and Comparative Endocrinology 96 149-161.

Prunet P, Boeuf G, Bolton JP \& Young G 1989 Smoltification and seawater adaptation in Atlantic salmon (Salmo salar): plasma prolactin, growth hormone, and thyroid hormones. General and Comparative Endocrinology 74 355-364.

Sakamoto T \& Hirano T 1991 Growth hormone receptors in the liver and osmoregulatory organs of rainbow trout: characterization and dynamics during adaptation to seawater. Journal of Endocrinology 130 425-433.

Sakamoto T, Ogasawara T \& Hirano T 1990 Growth hormone kinetics during adaptation to a hyperosmotic environment in rainbow trout. Journal of Comparative Physiology 160 B1-B6.

Sakamoto T, Iwata M \& Hirano T 1991 Kinetic studies of growth hormone and prolactin during adaptation of coho salmon, Oncorhynchus kisutch, to different salinities. General and Comparative Endocrinology 82 184-191.

Sambrook J, Fritcsh EF \& Maniatis T 1989 Molecular Cloning: a Laboratory Manual with the Laboratory Manual Source Book. Cold Spring Harbor: Cold Spring Harbor Laboratory Press. 
Shimizu M, Swanson P \& Dickhoff WW 1999 Free and proteinbound insulin-like growth factor-I (IGF-I) and IGF-I binding proteins in plasma of coho salmon, Oncorhynchus kisutch. General and Comparative Endocrinology 115 398-405.

Siharath K \& Bern HA 1993 The physiology of insulin-like growth factor (IGF) and its binding proteins in teleosts fishes. Proceedings of the Zoology Society of Calcutta, Haldane Communication Volume, pp 113-124.

Sjögren K, Liu JL, Blad K, Skrtic S, Vidal O, Wallenius V, LeRoith D, Törnell J, Isaksson OGP, Jansson JO \& Ohlsson C 1999 Liver-derived insulin-like growth factor I (IGF-I) is the principal source of IGF-I in blood but is not required for postnatal body growth in mice. PNAS 96 7088-7092.

Stefansson SO, Björnsson BTh, Hansen T, Haux C, Taranger GL \& Saunders RL 1991 Growth, parr-smolt transformation, and changes in growth hormone of Atlantic salmon (Salmo salar) reared under different photoperiods. Canadian Journal of Fisheries and Aquatic Sciences 48 2100-2108.

Yada T, Takahashi K \& Hirano T 1991 Seasonal changes in seawater adaptability and plasma levels of prolactin and growth hormone in landlocked sockeye salmon (Oncorhynchus nerka) and amago salmon (O. rhodurus). General and Comparative Endocrinology $8233-44$.

Yada T, Kobayashi T, Urano A \& Hirano T 1992 Changes in growth hormone and prolactin messenger ribonucleic acid levels during seawater adaptation of amago salmon (Oncorhynchus rhodurus). Journal of Experimental Zoology 262 420-425.

Yakar S, Liu JL, Stannard B, Butler A, Accili D, Sauer B \& LeRoith D 1999 Normal growth and development in the absence of hepatic insulin-like growth factor I. PNAS 96 7324-7329.

Young G, Björnsson BTh, Prunet P, Lin RJ \& Bern HA 1989a Smoltification and seawater adaptation in coho salmon (Oncorhynchus kisutch). Plasma prolactin, growth hormone, thyroid hormones, and cortisol. General and Comparative Endocrinology 74 335-345.

Young G, Prunet P, Ogasawara T, Hirano T \& Bern HA 1989 b Growth retardation (stunting) in coho salmon: plasma hormone levels in stunts in seawater and after transfer to fresh water. Aquaculture 82 269-278.

Received in final form 12 March 2001

Accepted 26 March 2001 